\title{
Urgency of a Spiritual-Psychological Integrative Approach in Overcoming Covid-19 Pandemic
}

\author{
Nurjannah* \\ Faculty of Dakwah and Communication \\ UIN Sunan Kalijaga \\ Yogyakarta, Indonesia \\ nurjannah@uin-suka.ac.id
}

\begin{abstract}
The world was shocked by the Corona virus outbreak that hit various countries, including Indonesia. The Task Force for the Acceleration of Covid-19 Handling reported that the total number of positive Indonesian citizens who contracted Covid-19 on April 24, 2020 was 8,211, with 1,002 recovered cases and 689 death cases. This paper intends to know the Indonesian government's policy in dealing with Covid-19, see its weaknesses, and provide input for approaches that are predicted to be effective. For this reason, literature studies are carried out in the form of thoughts, research results, and field experiences that have been published, with critical analysis so that strong intertwining is found to compile new concepts of integrative approaches. The results of the study reveal that the integrative approach with three approaches at once, i.e., medical, psychological and spiritual, is predicted to be effectively used to handle Covid-19 as suggested by several spiritual psychologists who have proven its effectiveness.
\end{abstract}

Keywords: Covid-19, integrative approach, spiritual psychology

\section{INTRODUCTION}

A novel coronavirus as a new strain is now becoming a new pandemic that has hit more than 180 countries in the world. The virus is named Coronavirus manifested in a disease so called Coronavirus Diseases 2019 (Covid-19), which is $75-80 \%$ similar to SARS-CoV. On February 24, 2020, this virus caused around 80,000 reported cases spreading in 28 more countries. On 30 January 2020, the WHO declared that the outbreak as a public health emergency of international concern therefore issuing a series of recommendations [1].

Covid-19 as a virus that causes an infectious disease can lead a patient to death. Therefore, medical scientists have tried their best to find a vaccine for this case. However, until now, an effective vaccine or antiviral drug specifically for this virus has yet to be found. For this reason, strict preventive and control measures to minimize the risk of possible transmission need enforcing [2].

According to medical scientists, this virus can be deactivated by heating at $56^{\circ} \mathrm{C}$ for 30 minutes and by using lipid solvents such as $75 \%$ ethanol, chlorine-containing disinfectants, peroxyetetic acid, and chloroform. Several options can be considered to control or prevent emerging infections, including vaccines, monoclonal antibodies, oligonucleotide-based therapies, peptides, interferon therapy and small molecule drugs [3].

It is suspected that the Covid-19 transmission route is via droplets of fluids originating from breathing and direct contact. The incubation period is usually 3-7 days and can be extended to 14 days. Coronavirus can affect anyone, but people with pre-existing health problems and older people are thought to be at greater risk of developing severe symptoms [4].

Some infected patients only exhibit neurological symptoms as early symptoms, i.e., (1) headache, lethargy, unstable walking, and malaise; (2) cerebral hemorrhage; (3) brain infarction; and (4) other neurological diseases [5]. In severe cases, septic shock, metabolic acidosis, irreversible bleeding and coagulation dysfunction can even occur. Patients with mild cases with a good prognosis generally recover within 1-2 weeks after contracting the disease.

Regardless of its preparedness to respond to this pandemic, Indonesia is already exposed to Covid-19. The Government of Indonesia through the Task Force for the Acceleration of COVID-19 Handling reported that, on 16 April 2020, a total of 5,516 Indonesian citizens were positive to be infected with Covid-19, 548 recovered, and 496 died. The numbers increased by April 24, 2020, where the total positive, recovered, and death cases were respectively 8.211, 1,002 and 689 [6]. This data shows that in a week the increase in positive cases and those who died reached a sharp spike.

Regarding the number of victims that have not shown any decrease yet, this paper intends to find out on how the Indonesian government policies deal with Covid-19 which has infected Indonesian people, whether the policies to manage the Covid-19 case still contain weaknesses, and, is yes, what input must be given for the pandemic management can be effective.

\section{METHOD}

This paper intends to determine the government's policies in dealing with Covid-19, to criticize their weaknesses, and to propose a new concept to achieve the effectiveness of Covid-19 handling for the people of Indonesia. The data are collected from various sources including research results, experts' thoughts and government policies contained in various documents including journals, manuscripts and others, either printed or online. The data are analyzed using content analysis, to find the link so that strong support is summarized as a concept that can be accounted for in dealing with the Covid-19 pandemic.

\section{GOVERNMENT POLICY OF COVID-19 HANDLING}

In order to reduce the increasingly widespread Covid-19, the Indonesian government has set the protocol by issuing Circular Letters, including: Presidential Decree No. 12 of 
2020 on the determination of non-natural disaster in the spread of Coronavirus 19 (Covid-19) Disease as a National Disaster, and reaffirms that the handling of national disasters caused by the spread of Covid-19 is carried out by the Task Force for the Acceleration of Covid-19 Handling [7].

The Task Force has compiled Guidelines for Medical Rapid Response and Public Health Aspects of Covid-19:

1. Prevention at individual levels through personal hygiene and home cleaning;

2. Prevention at community level through limiting physical interaction;

3. Supports in health quarantine;

4. Self-protection efforts in public facilities;

5. Role of health institutions: community health center, other health facilities;

6. Epidemiological inquiry;

7. Role of provincial/regency/city Governments;

8. Role of village government, RT-RW, and health workers;

9. Role of social and community organizations; and

10.Role of volunteers.

When viewed in more depth, the government protocol to prevent transmission of the covid-19 pandemic is more likely to be medically physical. In fact, this contagious outbreak has enormous implications for psychological problems. Covid-19 also causes psychological distress, such as depression, anxiety, and stress. During the initial phase of pandemic in China, more than half of the respondents assessed the psychological impact on the moderate to severe category, and about one third reported moderate to severe anxiety. Psychosocial effects at the individual level revolve around feelings of fear of illness or dying, helplessness, and stigma [8].

On the other hand, psychological issues are closely related to religious spirituality, which requires religious spiritual figures to be present to provide support for mental strengthening. However, something can become a problem when, during this pandemic, one of its important policies, i.e., social distancing, can directly or indirectly lock the presence and role of the religious figures in overcoming the situation.

\section{ILLNESS AND THE URGENCY OF SPIRITUAL APPROACH}

The sick in general say, "I feel sick". These words are commonly spoken by people without receiving any criticism. In fact, the sentence contains urgent things that deserve to be criticized, i.e., pain that can be felt only when people are awake and not in a state of sleep. In a state of sleep, all organs of the human body are complete; however, besides people cannot feel pain, during sleep mouth will not talk, ears cannot hear, or brain cannot think. The question will appear around what makes this condition can occur. The answer leads us to the understanding that there is another element besides the physical body that makes it functional. In this case, Islam provides information that the element is "Soul" as in the verses of the Qur'an.

Al-Qur'an Surah As-Sajdah verse 9 tells us that physical bodies formed from sulbi (ovum and sperm) which then become various bodily functions including five senses can only function after receiving energy from the soul so that they can hear, see, feel, say, think, walk, and so on. It is created nothing else to carry out the function as a caliph
(Surah Al-Baqarah, 2: 30) as well as a servant of God (Surah Adz-Dzariyat: 6).

Based on these two verses, it is evident that the one who feels the pain is the Spirit. The body cannot do anything without the Spirit. If what feels the pain is the Spirit, and the body is an extension of the spirit to realize what is in the Spirit, the treatment of a disease is not perfect if it only focuses on the physical body and does not include the spirit element of the patient.

This criticism might be refuted, with the argument that the Ministry of Religious Affairs as the official state institution has a role in giving some rules for the prevention of Covid-19. Likewise, non-structural institutions such as the Indonesian Ulema Council (MUI) should provide the same things.

The roles of the Ministry of Religious Affairs are manifested, among other things, in giving reference to the Covid-19 Patient Body Management Protocol which includes taking care of the body, the body prayer, and the burial [9]. Its role is also shown in the implementation of worship, especially in the month of Ramadan.

The roles of the Indonesian Ulema Council (MUI) are, among others, by issuing fatwa:

1. Everyone is required to make efforts to maintain health;

2. People who have been exposed to the Corona virus must maintain and isolate themselves to prevent transmission;

3. Healthy people may leave Friday prayers and replace them with midday prayers at the residence;

4. All people must not hold worship activities that involve large numbers of people;

5. Actions that cause panic and/or public loss;

6. Muslims are advised to get closer to Allah SWT by increasing worship;

7. Muslims must support and obey government policies;

8. The community is expected to be able to accept people who have been declared negative and/or declared healed [10].

It is recognized that religious institutions both state official institutions and religious social institutions have played a significant role in participating in overcoming the Covid-19 pandemic for Muslim communities in Indonesia in particular. However, unfortunately the religious approach is still in form of a relative legal fatwa that regulates more physical affairs and has not yet entered the core human realm, i.e., the $R u h$ so that they become tough people who are not anxious and afraid excessively but still have hope for God's help and so on.

On the other hand, the arrangement of hearts and feelings is considered to be the domain of the discipline of Psychology and psychologists have also played a role in handling Covid-19 in Indonesia. The contributions of these psychologists both direct practices in the field and written forms, among others, are as follows:

"Tips Tetap Bahagia Saat Karantina Diri Hadapi Covid19 (Tips to Stay Happy When Self Quarantine to Face Covid-19)"; "Mindfulness: Upaya Psikis di Tengah Wabah Virus COVID-19 (Mindfulness: Psychic Efforts amid the COVID-19 Virus Outbreak)"; and "Optimisme Menghadapi Corona di Indonesia" (Optimism in Facing Corona in Indonesia)" [11], etc. 
Interventions were carried out using Dialectical Behavior Therapy (DBT) derived from cognitive-behavioral therapy. DBT-based psychological interventions for Covid-19 patients conducted in pregnant patients, involving mindfulness and relaxation exercises, pressure tolerance skills, and interpersonal relationship skills, effectively reduce depression and anxiety. This psychological intervention provides benefits for patients to avoid antidepressant or anxiolytic drugs [12].

On closer inspection, what is done by medical personnel and scientists, religious scientists as well as psychologists and psychological scientists is still partial and not comprehensive and integrative. In fact, the elements that exist in humans, i.e., body, brain, and soul are not separated from each other, with the Soul as the center, managed by the brain and carried out by the body or physique. Based on this, the.

\section{INTEGRATIVE APPROACH TO HANDLING COVID-19}

Covid-19 is a physical disease caused by a virus that is easily transmitted and causes anxiety for everyone. So covid19 cannot be treated with just one approach, which is medical. The anxiety and panic experienced by sufferers and people who are afraid of contracting it also needs to be overcome by using a psychological approach. Meanwhile, collaboration of medical and psychological approaches, although able to overcome problems, can be temporary and not permanent. Therefore, a spiritual approach is needed to grow strength that is more permanent. Thus, collaboration of medical, psychological, and spiritual approaches is needed for handling Covid-19.

The integrative approach involves religious spirituality in overcoming illness by using the power of ritual, with several considerations. Religious rituals are able to return a man to the center of who he is. In difficult times, such as facing life's problems, rituals offer transformative power. Rituals have a therapeutic function in overcoming various problems faced by humans [13].

Cognitive Behavioral Therapy (CBT) counseling techniques have been understood to be easy to apply and proven effective. However, because the problems a person faces often include spiritual and existential issues, combining spirituality and making meaning with CBT is ideal for this service. The CBT theoretical approach that is spiritually integrated by formulating a modified assessment style, formulation, initial therapy, cognitive restructuring, and behavior modification, needs to be done to achieve the effectiveness of this integrated approach [14].

\section{CONCLUSION}

After careful analysis based on data from various sources, this study concluded that the handling of Covid-19 applied by the Indonesian government still prioritizes the medical approach. Psychological and religious approaches are also applied by various parties who care, but still go their separate ways and are not truly integrative. Based on the argument that, in addition to having physical aspects, humans also own soul and spirit aspects. Therefore, an integrative approach with three approaches at once, i.e., spiritual, psychological, and spiritual is recommended to use in handling Covid-19 as suggested by several spiritual psychologists who have proven its effectiveness.

\section{REFERENCES}

[1]. Nirmal Kandel et al, "Health security capacities in the context of COVID-19 outbreak: an analysis of International Health Regulations annual report data from 182 countries", Elsevier, Vol 395, March 28, 2020

[2]. Kuldeep Dhama et al, "COVID-19, an emerging coronavirus infection: advances and prospects in designing and developing vaccines, immunotherapeutics, and therapeutics". Human Vaccines \& Immunotherapeutics, 2020.

[3]. Zhi-Min Chen et al, "Diagnosis and treatment recommendations for pediatric respiratory infection caused by the 2019 novel coronavirus", World Journal of Pediatrics, 2020.

[4]. Nevin Hatipoğlu, "The New Problem of Humanity: New Coronavirus (2019-nCoV / COVID-19) Disease”, Med J Bakirkoy, 2020;16 (1):1-8.

[5]. Hai-Yang Wang et al, "Potential neurological symptoms of COVID19". Ther Adv Neurol Disord, 2020, Vol. 13: 1-2.

[6]. https://www.covid19.go.id

[7]. Keputusan Presiden Nomor 12 Tahun 2020

[8]. Cuiyan Wang et al, "Respons Psikologis Segera dan Terkait Faktor selama Tahap Awal 2019 Penyakit Coronavirus (COVID-19) Epidemi di antara Populasi Umum di Tiongkok". Int. J. Environ. Res. Public Health, 2020, 17, 1729.

[9]. Dirjen Bimas Islam Kemenag RI, Protokol Pengurusan Jenazah Pasien Covid-19.

[10]. Fatwa Majelis Ulama Indonesia (MUI) Nomor 14 Tahun 2020.

[11]. http://buletin.k-pin.org/index.php/daftar-artikel/550-tips-tetap-bahagiasaat-karantina-diri-hadapi-covid-19

[12]. Jin-wen HUANG et al, "Dialectical behavior therapy-based psychological intervention for woman in late pregnancy and early postpartum suffering from COVID-19: a case report", Journal of Zhejiang University-SCIENCE B (Biomedicine \& Biotechnology), 2020

[13]. Holly Nelson-Becker \& Kimberly Sangster, "Recapturing the power of ritual to enhance community in aging", Journal of Religion, Spirituality \& Aging, 2019, 31:2, 153-167,

[14]. Jill Snodgrass (2009). “Toward Holistic Care: Integrating Spirituality and Cognitive Behavioral Therapy for Older Adults", Journal of Religion, Spirituality \& Aging, 2009, 21:3, 219-236. 